\title{
Family socialization and educational attainment
}

Citation for published version (APA):

van der Velden, R. K. W. (1992). Family socialization and educational attainment. Researchcentrum voor Onderwijs en Arbeidsmarkt, Faculteit der Economische Wetenschappen. ROA Research Memoranda No. 6E https://doi.org/10.26481/umaror.199206E

Document status and date:

Published: 01/01/1992

DOI:

10.26481/umaror.199206E

Document Version:

Publisher's PDF, also known as Version of record

\section{Please check the document version of this publication:}

- A submitted manuscript is the version of the article upon submission and before peer-review. There can be important differences between the submitted version and the official published version of record.

People interested in the research are advised to contact the author for the final version of the publication, or visit the DOI to the publisher's website.

- The final author version and the galley proof are versions of the publication after peer review.

- The final published version features the final layout of the paper including the volume, issue and page numbers.

Link to publication

\footnotetext{
General rights rights.

- You may freely distribute the URL identifying the publication in the public portal. please follow below link for the End User Agreement:

www.umlib.nl/taverne-license

Take down policy

If you believe that this document breaches copyright please contact us at:

repository@maastrichtuniversity.nl

providing details and we will investigate your claim.
}

Copyright and moral rights for the publications made accessible in the public portal are retained by the authors and/or other copyright owners and it is a condition of accessing publications that users recognise and abide by the legal requirements associated with these

- Users may download and print one copy of any publication from the public portal for the purpose of private study or research.

- You may not further distribute the material or use it for any profit-making activity or commercial gain

If the publication is distributed under the terms of Article $25 \mathrm{fa}$ of the Dutch Copyright Act, indicated by the "Taverne" license above, 


\section{FAMILY SOCIALIZATION AND EDUCATIONAL ATTAINMENT*}

ROA-RM-1992/6E

R.K.W. van der Velden

\section{RESEARCH CENTRE FOR EDUCATION AND THE LABOUR MARKET}

Faculty of Economics and Business Administration

Rijksuniversiteit Limburg

Maastricht, November 1992

* This paper was presented at the Midterm Conference of the ISA Research Committee Sociology of Education, July 1992, Amsterdam. The research was carried out at the Institute for Educational Research (RION) in Groningen, with a grant from SVO (SVO-project 4229). The author is now Chief Researcher at the Research Centre for Education and the Labour Market (ROA) at the University of Limburg. All correspondence should be sent to Rolf van der Velden, ROA, P.O. Box 616, 6200 MD Maastricht, The Netherlands. 
CIP-GEGEVENS KONINKLIJKE BIBLIOTHEEK, DEN HAAG

Velden, R.K.W. van der

Family socialization and educational attainment / R.K.W. van der Velden. - Maastricht: Research Centre for Education and the Labour Market, Faculty of Economics and Business Administration, Rijksuniversiteit Limburg. - III. -

(ROA-RM-1992/6E)

Met lit. opg.

ISBN 90-5321-093-8 in spiraalband

Trefw.: onderwijs en sociaal milieu. 
CONTENTS

Page

1. INTRODUCTION 1

2. DATA AND METHOD 3

3. SELECTION PROCESSES IN THE EDUCATIONAL CAREER 6

4. A FAMILY MODEL $\quad 8$

5. CONCLUSIONS 14

$\begin{array}{ll}\text { REFERENCES } & 15\end{array}$ 


\section{INTRODUCTION}

The relationship between social status and educational attainment is perhaps one of the most stable in sociological research. The systematic disadvantage of pupils from lower social classes in achieving the higher educational levels is well documented (Hallinan, 1988; Dronkers, 1990), and has a prominent position on the public policy agenda. In most countries this has given rise to large-scale programmes providing extra educational support for children of lower social classes. Despite these efforts, the overall relationship between social status and educational attainment is rather stable over time (Peschar, 1989), although in the long run the effects seem to diminish (Hout, 1988, Ganzeboom \& De Graaf, 1989). International comparisons show that there is little difference in this respect between countries, despite large differences in educational and social policy (Peschar, 1978; 1987).

The literature reveals two major theoretical notions about the process underlying the relation between social status and educational attainment. An elaborated research programme has been carried out by Kohn and his associates (Kohn, 1977; Kohn \& Schooler, 1983). Their assumption is that life conditions, and in particular job conditions, have a great impact on the values and orientations that one holds. The essence of the working life of the higher social strata is the opportunity to exercise occupational self-direction, that is to use initiative, thought and independent judgement. This fosters a view of self and society in which success is attributed to individual capacities and efforts and promotes the positive valuation of self-direction. On the other hand, life conditions of the lower social strata foster a more traditional, externally oriented view of social reality and promote the positive valuation of conformity to authority. The feeling of being at the mercy of social powers over which no influence can be exerted and the working of which is often even not clear is characteristic for people who perform simple routine work that is assigned to them by others. Conformity is the answer to life conditions in which there appears to be no room for self-direction. Obedience to superiors, interest in the extrinsic characteristics of one's work, little confidence in others and a rigid attitude towards anything considered deviant characterize the self-image and orientation of the lower social strata. These 'lessons of work' are passed on to other aspects of life in a process of 'learning generalization', particularly to child-rearing. Parents train their children for the world as they see it. In bringing them up they stress conformist values, when conformism appears to be important and necessary in their own lives, whereas self-direction is stressed when it is fostered by the parents' own life conditions and work conditions. This theory has been confirmed, sometimes partially, by replication in several countries (Slomczynski et al. 1981; Naoi \& Schooler, 1981). However the effect of parents' valuation of self-reliance on the educational career of their children has not yet been clearly demonstrated. The argument appears to be here that stress on self-direction and self-reliance means that children grow up in an environment which makes more demands on their intellectual flexibility and is more conducive to the development of analytical and problem-solving skills (Schooler, 1972; Kohn, 1977).

According to Bourdieu (Bourdieu \& Passeron, 1977; Collins, 1979; Bourdieu, 1984; DiMaggio, 1982 ), it is cultural capital which plays a dominant role in the persistence of status across the 
generations. One central element in the reproduction process is what Bourdieu denotes as the habitus: the whole of linguistic and cultural competence and affinities, which are acquired especially in primary socialization. This involves differences in the use of language and language codes, aesthetic preferences, consumer patterns, recreation and attitude towards education: in short the lifestyle characteristics by which the status groups differentiate themselves. Every status group has its own habitus. In order to be able to function in the educational system, familiarity with the culture of the dominant status groups is assumed. This means in the first place familiarity with and appreciation of the 'official' culture, the culture with a capital C (De Graaf, 1987). This form of capital, cultural capital, is acquired in the early childhood. Socialization in the family in particular has a determining influence: that is where the foundations for the appreciation of certain artistic expressions are laid and where taste preferences are internalized. Schools cannot bridge such differences in cultural capital. On the contrary, the manner in which schools transmit knowledge, the assumed codes and expected competencies, enhance the differences that already exist. If one is to 'feel at home' in the official culture the basis has to have been laid in the parental environment: it cannot be simply acquired along with the knowledge given by the school. The gap between school and home culture for children from the lower strata means not only that knowledge is offered in a form impenetrable to them, it also implies the development of subtle forms of selection and selfselection, due to which these children drop out and leave education sooner. On the one hand this is because they feel less confident in the higher and more prestigious types of education, and on the other hand there is a direct selection, because teachers in their role as 'gatekeepers' have a certain preference for pupils from the higher strata (Rosenbaum, 1976; Jungbluth, 1984).

The two theories differ in where they place the stress as regards both social position and the characteristics of the socialization process. Furthermore they differ in the scope of their explanation. The theory of Kohn is solely related to what Boudon (1974) denotes as the primary effects of social stratification: the effect of social background on cognitive development. Bourdieu's theory on the other hand covers the primary as well as the secondary effects of social stratification: apart from the effect on school performance also the effect on the choices made by pupils. In this article the empirical explanatory power of the two theories is tested. The research questions are:

1. At which stages of the educational career does social status manifest its influence?

2. To what extent do the differences in the orientation to self-direction of parents and the differences in cultural capital, respectively, offer empirical explanations for the relationship between social origin and the educational position attained?

3. In which period in the educational career do these family characteristics exert their influence. 


\section{DATA AND METHOD}

In 1972 a group of researchers from the Department of Sociology at the University of Groningen started a longitudinal study into the effects of social background on cognitive development (Meijnen, 1977; 1984). It was decided to follow a sample of 728 children who entered primary education in the city of Groningen. Each of them was given an intelligence test at the ages of 6,9 and 12, and a school performance test at 9 and 12 . In 1972 interviews were also held with the children's mothers, while a questionnaire was left behind for the fathers. Information was gathered on social-structural variables such as education, occupation and family size as well as on the values and orientations of the parents towards education, society and child-rearing and on the parents' cultural habits. In 1975 and 1978 information about the schools attended by the children was gathered.

When the pupils were 18 years old (i.e., in the year 1984) they were approached once more, this time by the Institute for Educational Research (Bosker et al, 1985; Bosker 1990; Van der Velden, 1991). Detailed information about their career in secondary education was obtained from the pupils themselves, while further information about family background and schools attended was again gathered by interviews with parents and school personnel. Compared to the situation in 1972, the 1984 survey had an experimental loss of $22 \%$, due to non-response and non-availability (address unknown etc.). The present analysis will use data from the surveys of 1972 and 1984. Pupils who were referred to special education have been left out (only a short adapted interview was held with their mothers), as have pupils for whom there is no information from the mother. A total of 519 complete sets for pupils and mothers remain. Some of these 519 sets contain data from fathers: in 450 cases from the 1972 survey and 349 cases from the 1984 survey. The lower response of fathers, especially in 1984 , is mainly due to refusals $(18 \%)$ and divorce $(9 \%)$.

Although the surveys from 1972 and 1984 have different accents, information concerning the orientation of the parents towards self-direction was gathered at both times, as was information concerning the parents' cultural habits. The variables which were selected for the present analyses refer to four different aspects: social status, educational career, orientation of the parents to self-direction and the family's cultural capital.

The first set indicate the social status of the family, which is defined as a composite score of the educational level of both parents and the occupational prestige of the father.

The second set of variables relate to the educational career of the children. The variables here concern the differences in intelligence at the start of primary education, measured by four different intelligence tests, the educational position at the end of primary education and the educational position at the age of 17 . The educational position at the end of primary education reflects both the teacher's advice as to the type and level of secondary education to which they are suited (ranging from lower vocational education to preparatory university education) and the number of times the pupil repeated years. The educational position at age 17 reflects the 
(highest) year and level reached in secondary education.

The third set of variables relate to the parents' valuation of self-direction. Three variables refer to this dimension. The first concerns the 'parental child-rearing values' and is derived from Kohn. The parents were presented with ten child-rearing values. Five of these stress selfdirection. The other five relate to conformity values. The task was to select the three most important and the three least important. Both parents were asked, in 1972 as well as in 1984 A high score indicates a strong valuation of self-direction. The second variable is a scale for the 'social orientation' of the parents, again for both parents, in 1972 and in 1984. A high score indicates an open, non-conformist vision of society. The third variable represents the 'role structure' between mother and child and was operationalized by means of questions on the nature of a) role prescriptions, b) sanctions, c) verbal interaction and d) independence training. A high score indicates a personal role structure, a low one indicates a positional role structure.

The fourth set of variables concerns the cultural capital in the family. In the first place, the 'reading behaviour of the parents' was looked at, in 1972 and 1984. The scale concerned is made up of items that indicate whether the respondents subscribed to newspapers and weekly magazines, and how much time they generally spent on reading books and newspapers. A high score indicates a strong reading orientation. The variable 'cultural pedagogy level' indicates the extent to which parents give impetus to the cognitive development of the children. It deals with matters such as reading to them, learning songs, correcting word use or buying readers. This cultural-pedagogy level was determined for the father as well as for the mother, but only in 1972. A high score indicates a high cultural-pedagogy level. The variable 'understanding of the educational system' indicates the extent to which parents are informed about the standards and the written and unwritten rules of the educational system. A high score indicates good understanding. The data was collected in 1984, from the mothers. A closely related indicator is the 'nearness to the educational field'. The parents were asked whether they have acquaintances who work in education, or whether they themselves have worked or are working in education. It is assumed that the closer one is to the educational system, the more familiar one is with the prevailing standards and rules. Finally, there are two variables that say something about the involvement of parents in the educational careers of their children. For the first variable, 'knowledge of the subjects chosen', the mother was asked to name the subjects her son or daughter chose in school. In addition, the parents are asked how much information they gathered when the choice of subjects was being made.

The analyses were carried out with LISREL VI (Jöreskog and Sörbom, 1986) using maximum likelihood estimation, applied to covariance matrices with a list-wise deletion of missing values. Several models $(K=1,2 \ldots . ., g)$ were compared and the likelihood ratio goodness-of-fit statistic was used as an indication as to which model best approximates to the data. A major problem with finding a best fitting model in such a way is that no information is gained about the stability of the chosen model, nor is it clear to what extent chance capitalization has occurred. We therefore follow a strategy of double cross-validation, suggested by Cudeck and Browne (1983). We split our sample randomly in two equal halves, a and b. Sample a is used as a 
calibration sample. The different models $(k=1,2 \ldots \ldots g)$ are developed using this sample. These models are then cross-validated on sample $b$, the validation sample. The cross-validation index $F\left(S_{b} ; \hat{E}_{k \mid a}\right)$ is a measure of the discrepancy between the covariance matrix for the validation sample $\left(S_{b}\right)$ and the reproduced covariance matrix for the calibaration sample $\left(\hat{E}_{k \mid a}\right)$, where $k$ is the model under consideration. This results in a set of $\mathrm{g}$ cross-validation indices. This procedure is repeated by calculating for each model $K$ the cross-validation index $F\left(S_{b} ; \hat{E}_{k \mid a}\right)$. This results in a second set of cross-validation indices (double cross-validation). If the same model yields the lowest cross-validation index in each set, then we may be confident that this model has the greatest predictive validity for the given sample size. All presented models are analyzed in this way and they can all be uniquely identified. 


\section{SELECTION PROCESSES IN THE EDUCATIONAL CAREER}

The first research question we address is: at which stages of the educational career does social status manifest its influence? Status effects in a given period may be partly due to status effects in an earlier period. In order to separate direct status effects from indirect effects (i.e. effects due to a status effect on former educational positions) we constructed a longitudinal model. The various educational positions are therefore depicted on a time line. We use a latent variable INTELL, indicated by the four 10 subtests 101 to 104 , to mark the differences in intelligence which are already apparent at the start of primary education (age 6). The variable PRIMPOS marks the educational position reached at the end of primary education and the variable ENDPOS represents the position reached at age 17. As exogenous variable we use the variable STATUS, a composite score of the education of both parents and the occupation of the father in 1972.

Table 1. Measurement model INTELL $(n=519)$

no correlation measurement errors Indicator

1. 101: verbal subtest

2. 102: perception subtest

1.00

1.18

.11

3. 103: numerical subtest

1.40

1.11

.10

4. 104: spatial subtest

.09

Modification: $10 \chi^{2}$-points correlation 1-3 and

$10 \chi^{2}$-points correlation $2-4$

coefficient of determination $=.79$

$\chi^{2}=14.0$ d.f. $=2 \quad p=.001$

The estimates for the measurement model of INTELL are presented in table 1 . In this model no correlation of error terms is allowed. The coefficient of determination indicates a rather reliable instrument. The overall fit $\left(\chi^{2}=14.0 ;\right.$ d.f. $\left.=2\right)$ is not very good, but can be improved significantly by introducing correlated measurement errors on $101-103$ and $102-104$. As these two pairs represent respectively verbal and non-verbal intelligence, this modification seems to be justified. We therefore accepted this model with the mentioned modification as representing intelligence.

The next step in the analysis was the development of a longitudinal model, in order to assess the direct and indirect effects of STATUS on the different stages of the educational career. As was said above, we used the first half of the sample to develop the different models. Those models which had an acceptable fit were next double cross-validated. Figure 1 presents the resulting model based on this procedure. 


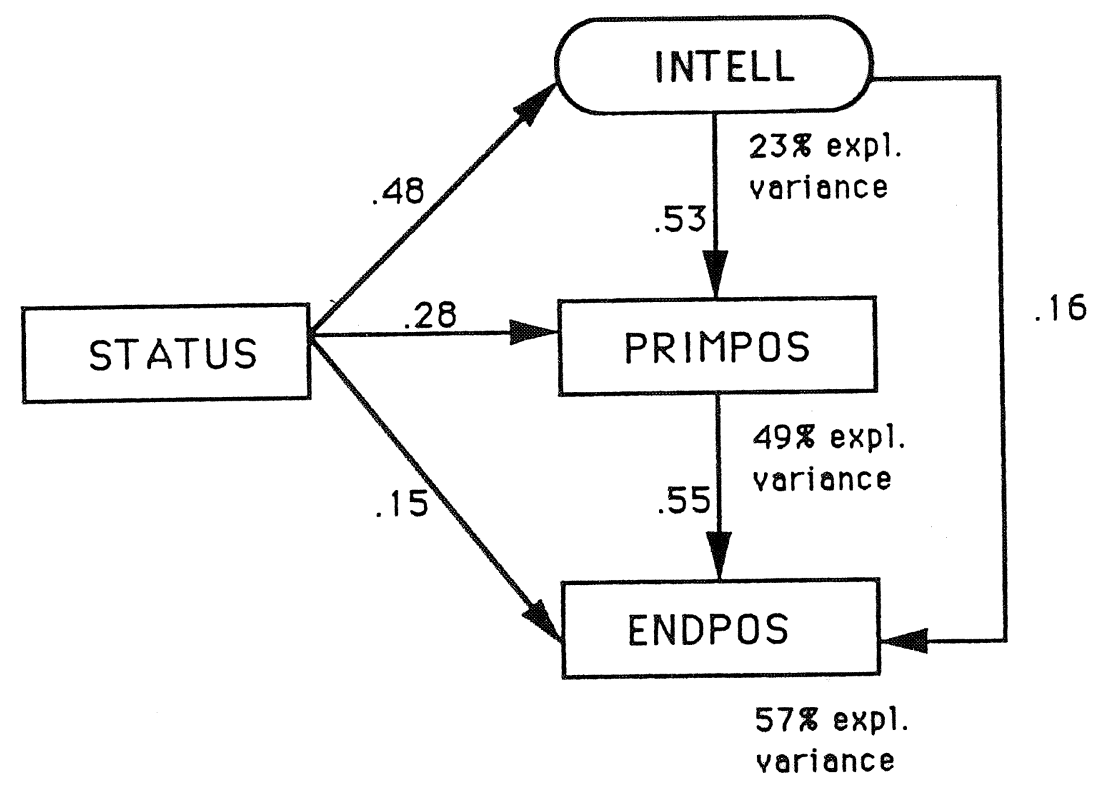

$\chi^{2}=14.3 ;$ d.f. $=9 ; p=.11$

All effects are significant at .05 level. The model shows that $49 \%$ to $57 \%$ of the variance in educational position at the end of primary education and at the age of 17 can be 'explained' in terms of the variables incorporated in the model. As the educational career develops, the direct effect of social status becomes weaker: from .28 for the period in primary education to .15 for the period in secondary education.

The total (direct and indirect) standardized effect of STATUS on the educational position at the age of 17 (ENDPOS) is .52. Of this total effect, .37 is indirect (due to earlier positions) and .15 is direct. The total effect of STATUS on the position at the end of primary education (PRIMPOS) is .53 , of which .28 is direct and .25 is indirect. Finally the total effect of STATUS on intelligence at the age of 6 (INTELL) is .48. We can also express these figures in a different way. If we set the total effect of social status on achieved educational position at the age of 17 at $100 \%$, one could say that $30 \%(=.15 / .52 * 100 \%)$ of this effect is due to selection processes in secondary education, $29 \%$ is due to selection processes in primary education, while $41 \%$ must be attributed to pre-school differences. These results indicate that the contribution of early cognitive development to later academic success is rather substantial. However, the larger part of the status-related differences in educational careers must be attributed to factors and processes which occur after entering education. This cumulation of the status effect with age points to an explanation in terms of different socialization patterns. In the next section we will analyze whether these effects of social stratification can to some extent be 'explained' by differences in the orientation of parents to self-direction or by differences in the family's cultural capital. 


\section{A FAMILY MODEL}

The next step in the analysis was the introduction of family characteristics in the longitudinal model, and more specifically of those variables which refer to the valuation of self-direction versus conformity and to cultural habits. We will first present the measurement models for the valuation of self-direction, separately for mothers and fathers. In measuring the mothers' orientation to self-direction, we started with a model in which we allowed for correlation of the error terms of the same indicators over time. The results of this model are presented in table 2. The total coefficient of determination is rather good $(.80)$ indicating that we have a rather reliable instrument. The overall fit is very good. No major modifications are indicated. We therefore accepted this model as representing mothers' orientation to self-direction.

Table 2. Measurement model 'self-direction mother' $(n=503)$

Correlated measurement errors: $1-2 ; 3-4$

Indicator

1. Parental values 1972

2. Parental values 1984

3. Social orientation 1972

4. Social orientation 1984

5. Role structure

No significant modifications

coefficient of determination $=.80$

$\chi^{2}=1.5$ d.f. $=3 \quad p=.69$
Lambda

1.00

.73

.73

5.79

5.28
Standard error

.07

.50

.42

Table 3. Measurement model 'self-direction father' $(n=305)$

No correlation of measurement errors

Indicator

1. Parental values 1972

2. Parental values 1984

3. Social orientation 1972

4. Social orientation 1984
Lambda

1.00

.90

.89

6.66
Standard error

.14

.15

1.06

modifications: $\quad 5.4 \chi^{2}$-points correlation 1-2 and

$5.4 \chi^{2}$-points correlation $3-4$

coefficient of determination $=.67$

$\chi^{2}=7.1$ d.f. $=2 p=.03$ 
The estimates of the measurement model for the father are presented in table 3 . In this model we do not allow for the correlation of error terms, due to the lack of degrees of freedom. The overall fit of the model for the father is rather bad $\left(\chi^{2}=7.1\right.$; d.f. $\left.=2\right)$, but this can be significantly improved if we allow the error terms of the same indicators to correlate over time. The total coefficient of determination (.67) is lower than for the mother. This difference is perhaps due to the fact that information about the father was gathered using a questionnaire instead of an interview. Despite this lower reliability we will use the model as a representation of fathers' orientation to self-direction, although we should be aware that, as a result of the low reliability, any effects of the fathers' self-direction may prove not to be significant.

Table 4. Measurement model 'cultural capital' $(n=473)$

Correlated measurement errors: $1-2,5-6$

Indicator

Lambda

Standard error

1. Reading behaviour 1972

1.00

2. Reading behaviour 1984

1.09

3. Understanding of education

5.75

.11

4. Nearness to education

.43

.74

5. Cult.ped.level mother

3.19

.06

6. Cult.ped.level father

.41

7. Information on choice of subjects

.08

8. Knowledge of the subjects

modifications: $\quad 6.5 \chi^{2}$-points correlation 5-7;

$6.0 \chi^{2}$-points correlation 4-7 and

$5.5 \chi^{2}$-points correlation 1-6

coefficient of determination $=.70$

$\chi^{2}=25.2, \mathrm{df}=18, \mathrm{p}=.12$

The measurement model for cultural capital comprises eight indicators (table 4). In the model, correlation was assumed between measurement errors for the reading behaviour in 1972 and 1984 and between the cultural-pedagogic level of the mother and that of the father. The coefficient of determination and the model fit are reasonable. The model fit could be improved if correlated measurement errors are also assumed between certain other variables. However, no theoretical justification can be found for this, so these modifications were not adopted. The model as it is presented here was accepted for the coming analyses.

In figures 2 to 4 , the parameter estimates of the structural family models are given. All three of these models were created using double cross-validation, as described earlier. The corresponding table, table 5, shows how great the total (direct plus indirect) status effect is on the different career variables and what part of it is mediated by the family characteristics concerned. 
Figure 2. Self-direction mother

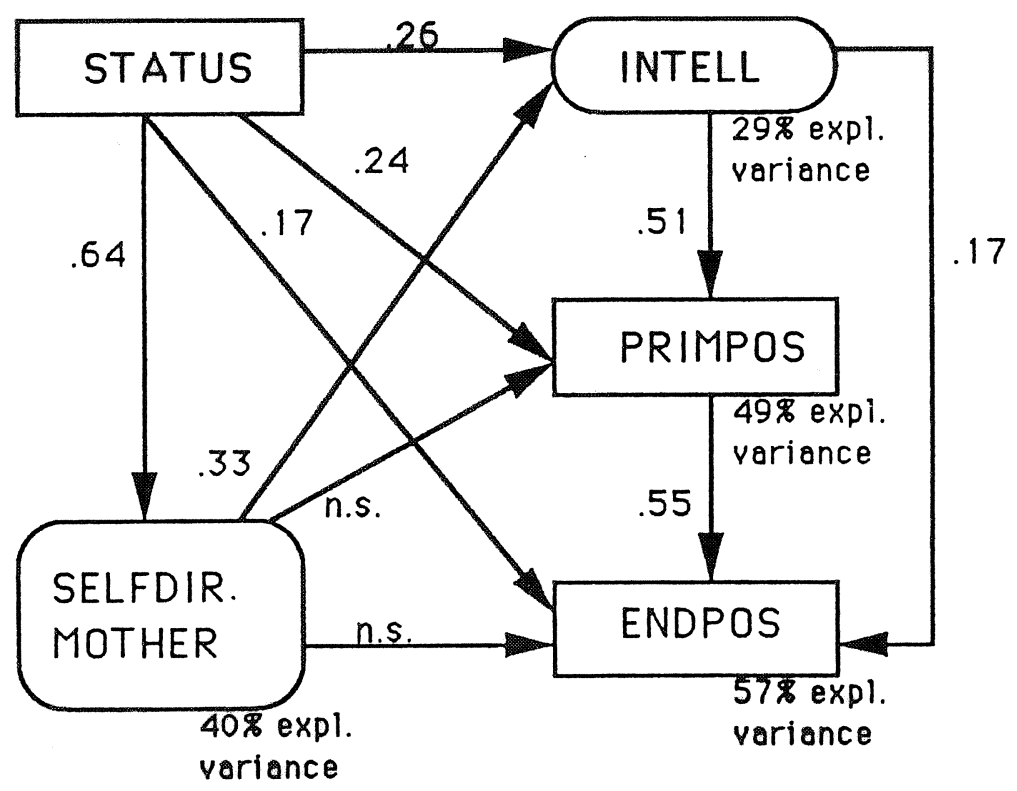

$\chi^{2}=49.7 ; \mathrm{df}=43 ; p=.22$

Figure 3. Self-direction father

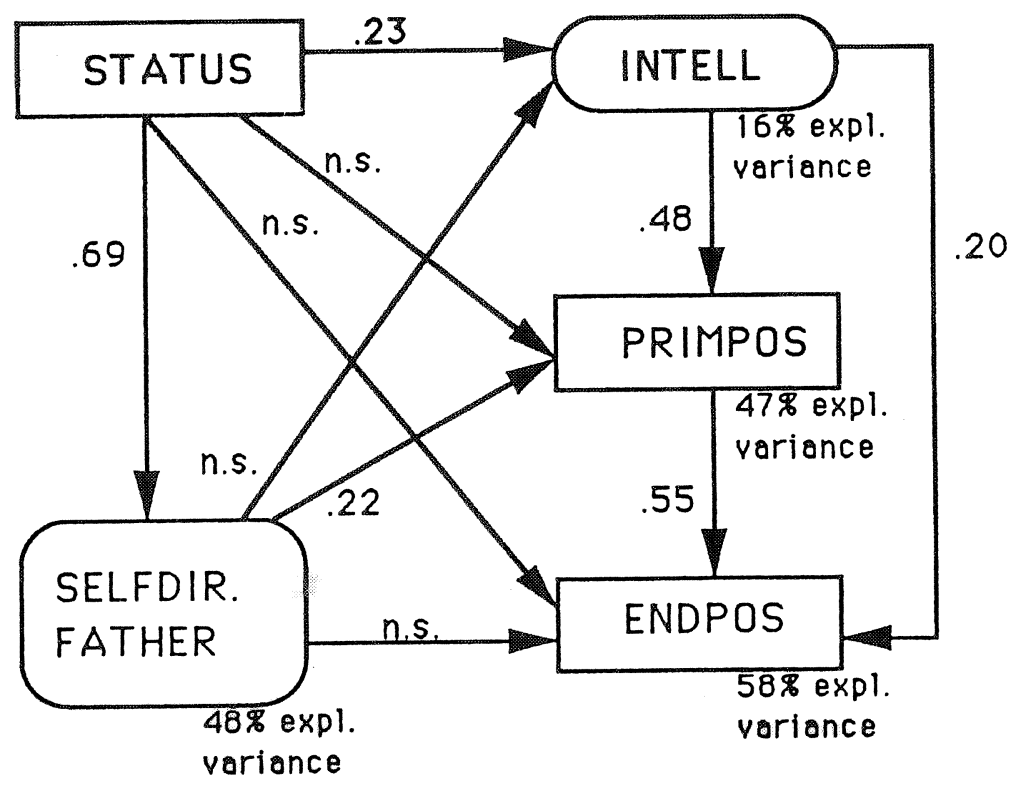

$\chi^{2}=43.9 ; \mathrm{df}=33 ; \mathrm{p}=.10$ 
Figure 4. Cultural capital

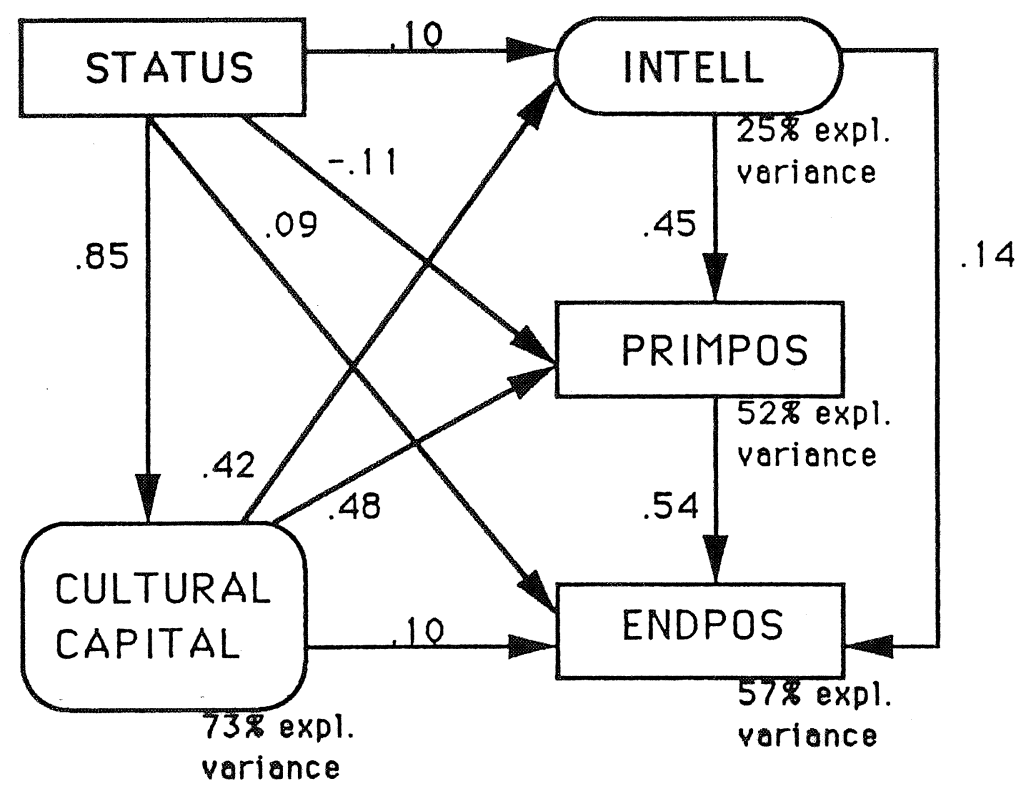

$\chi^{2}=122.4 ; d f=79 ; p=.001$

Table 5. Effect of STATUS and the mediating role of family characteristics

$\begin{array}{llll}\text { Status effect } & \begin{array}{l}\text { Self-direction } \\ \text { mother }\end{array} & \begin{array}{l}\text { Self-direction } \\ \text { father }\end{array} & \begin{array}{l}\text { Cultural } \\ \text { capital }\end{array}\end{array}$

\begin{tabular}{|c|c|c|c|}
\hline $\begin{array}{l}\text { Total effect STATUS on ENDPOS } \\
\text { mediated via family characteristic }\end{array}$ & $\begin{array}{r}.51 \\
19 \%\end{array}$ & $\begin{array}{r}.46 \\
36 \%\end{array}$ & $\begin{array}{r}.50 \\
87 \%\end{array}$ \\
\hline effect STATUS in secondary education & .14 & .12 & .17 \\
\hline mediated via family characteristic & negative & $10 \%$ & $50 \%$ \\
\hline effect STATUS in primary education & .29 & .30 & .30 \\
\hline mediated via family characteristic & $16 \%$ & $52 \%$ & $100 \%$ \\
\hline effect STATUS pre-school & .47 & .37 & .45 \\
\hline mediated via family characteristic & $44 \%$ & $39 \%$ & $79 \%$ \\
\hline
\end{tabular}

The degree to which the different models fit the data varies considerably. The model with the self-direction orientation of the mother appears to fit the data quite well $\left(\chi^{2}=49.7 ; \mathrm{df}=43\right.$ ). The other two models appear to fit the data reasonably, considering the relation between the chi $^{2}$ value and the number of degrees of freedom. When comparing the model with 'father's self-direction' with the other models, one has to bear the difference in the sample size in mind. 
The effect of social status on the latent variable cultural capital is very strong (.85). This means that the cultural capital of a family is to a considerable extent determined by the social position of the parents. For the other models, the effect of social status on the latent variables is less important: .64 for 'mother's self-direction' and .69 for 'father's self-direction'. Obviously, the unexplained variance in these intermediating variables also differs because of this: from $27 \%$ for 'cultural capital' to $60 \%$ for 'mother's self-direction'.

The relations between the various career variables hardly differ between the 3 models and agree reasonably well with the estimates from the longitudinal model in the previous section. In all models, intelligence at the age of 6 (INTELL) has a strong effect on the position at the end of primary school (PRIMPOS), which in turn strongly determines the end position (ENDPOS). Weak direct effects were found between intelligence and the end position.

What does differ is the intermediating role of family characteristics. Cultural capital appears to have a strong effect on the educational career, in particular on the first two career variables of intelligence (.42) and position at the end of primary school (.48). For the other two models, the effects of family characteristics are much weaker. The orientation to self-direction of the mother has a strong effect on the intelligence (.33), whereas its effects on the other two career variables do not significantly deviate from zero ( $t$-value $<1.96$ ). The orientation to selfdirection of the father has a significant effect only for the position attained at the end of primary school (.22). Because of the differences in the intermediating role of the family characteristics, the direct effects of social status on the career variables also vary, being smallest in the cultural capital model and greatest in the model with the orientation to selfdirection of the mother. The intermediating effect of cultural capital is thus demonstrable in every career period whereas self-direction values have a positive effect only at certain moments in the career.

The unexplained variance in the different career variables hardly varies between the three models and does not deviate substantially from the unexplained variance found in the model without family characteristics from the last section. This indicates that the family characteristics concerned intermediate part of the status effect, but do not have an 'extra' explanatory value. They therefore do not contribute to a better forecast of the educational career, but they do indicate the processes through which the status effects work. The measure to which the family characteristics mediate the status effect does vary however. Cultural capital appears to mediate $87 \%$ of the total status effect. When the effect of social status on the separate career periods is contemplated, the differences in cultural capital explain $50 \%$ of the status effect on the career in secondary education, the whole status effect on the career during primary school, and $79 \%$ of the status effect on the intelligence at age 6 . The intermediating role of orientations to self-direction is much lower. Differences in orientation to self-direction of the mother explain only $19 \%$ of the total effect of status on the educational career. A strong orientation to self-direction of the mother appears to be relevant only in the pre-school period, where it explains $44 \%$ of the status effect. The intermediating role of the orientation to selfdirection of the father appears to be somewhat larger, mediating a total of $36 \%$ of the status 
$-13-$

effect (some caution in interpretation is called for, because of the different sample size). A strong orientation to self-direction on the part of the father explains $52 \%$ of the status effect on the career during primary school and $39 \%$ of the status effect on the pre-school period. 


\section{CONCLUSIONS}

The influence of social background on the educational career is quite large and manifests itself at different stages of the educational career. If we set the total effect of social status on achieved educational position at the age of 17 to $100 \%$, one could say that $30 \%$ of this effect is due to selection processes in secondary education, $29 \%$ is due to selection processes in primary education, while $41 \%$ must be attributed to pre-school differences. These results indicate that the contribution of the cognitive development in early childhood to later academic success is quite large. Most of the status-related differences in the educational career must however be attributed to factors and processes which occur after entering education.

The cumulative effect of social background on the educational career strongly supports an explanation of unequal educational opportunity in terms of differences in socialization. In this article, the empirical explanatory power of the two main theories in this domain, Kohn's theory of self-direction and Bourdieu's theory of cultural capital are closely examined. The analyses show that the orientation to self-direction of the parents explains only a part of the status effect. Less than half of the status effect in the pre-school period appears to be related to the orientation to self-direction of the parents, whereas about half the career in primary education appears to be related with the orientation to self-direction of the father. Differences in cultural capital appear to give a better explanation for the relation between social status and educational career. This applies in particular to the effects of social status in the pre-school and primary school period. Differences in cultural capital were seen to relate to only half of the status effect on the career in secondary education. If we consider the status effect on the career in secondary education as mainly a secondary effect of social stratification, then one can say that differences in cultural capital explain the larger part of the primary effects and part of the secondary effects. Thus social inequality in educational opportunities appears to relate primarily to differences in cultural capital. It is not attitudes to self-direction but the differences in habitus which lie at the basis of status-specific selection in education. Still, this is only part of the story. It is true that differences in cultural capital appear to mediate the status effect well, but they do not add anything extra. The total explained variance in the attained educational position appears to be just as great in the extended family model as in the limited longitudinal model. Moreover, the status effect during secondary education is only partly determined by differences in cultural capital. Apparently other factors, such as social resources, also play a role. In future research these other factors in particular will have to receive attention. 


\section{REFERENCES}

Bosker, R.J., Hofman, W.H.A. \& Velden, R.K.W. van der (1985a). Een generatie geselecteerd. Deel 1: De loopbanen. Groningen: RION.

Bosker, R.J. (1990). Extra kansen dankzij de school? Het differentieel effect van schoolkenmerken op loopbanen in het voortgezet onderwijs voor lager versus hoger milieu leerlingen en jongens versus meisjes (dissertatie). Nijmegen: ITS.

Boudon, R. (1974). Education, Opportunity and Social Inequality. New York: John Wiley \& Sons.

Bourdieu, P. \& Passeron, C. (1977). Reproduction in education, society and culture. Parijs: Minuit.

Bourdieu, P. (1984). Distinction, a social critique of the judgement of taste. London: Routledge and Kegan Paul.

Collins, R. (1979). The credential society. New York: Academic Press.

Cudeck, R. \& Browne, M.W. (1983). Cross-validation of covariance structures. Multivariate Behavioral Research, 18, 147-167.

DiMaggio, P. (1982). Cultural capital and school success: the impact of status culture participation on the grades of US high school students. American Sociological Review, 47, 189-201.

Dronkers, J. (1990). De ontwikkelingen in het schoolloopbaanonderzoek: een terugblik op een decennium. Tijdschrift voor Onderwijsresearch, 15, 1, 8-22.

Ganzeboom, H.B.G. \& Graaf, P.M. de (1989). Verandering van onderwijskansen in Nederland tussen 1900 en 1980. Mens en Maatschappij, Special number 1989, 58-78.

Graaf, P.M. de (1987). De invloed van financiële en culturele hulpbronnen in onderwijs/oopbanen (dissertatie). Nijmegen: ITS.

Hout, M. (1988). More Universalism, Less Structural Mobility: The American Occupational Structure in the 1980's. American Journal of Sociology, 93, 1358-1400.

Jöreskog, K.G. \& Sörbom, D. (1986). LISREL VI. Analyses of linear structural relationships by the method of maximum likelihood. User's guide. 4th edition. Uppasala: University of Uppsala. 
Jungbluth, P.L.M. (1984). Herkomst, milieu en sekse van leerlingen in relatie tot leerkrachtverwachtingen; impliciete selectie in het basisonderwijs. Pedagogische Studiën, 61, 402-411.

Kohn, M.L. (1977). Class and conformity. A study in values. 2nd edition. Chicago: University of Chicago Press.

Kohn, M.L. \& Schooler, C. (1983). Work and personality: an inquiry into the impact of social stratification. Norwood: New Jersey.

Meijnen, G.W. (1977). Maatschappelijke achtergronden van intellectuele ontwikkeling. (dissertatie). Groningen: Wolters-Noordhoff.

Meijnen, G.W. (1984). Van zes tot twaalf. Harlingen: Flevo-druk.

Naoi, A. \& Schooler, C. (1981). Occupational conditions and psychological functioning in Japan. Paper presented at the annual meeting of the American Sociological Association, August 1981.

Peschar, J.L. (1978). Educational opportunity within and between Holland and Sweden. The semi-experimental approach. Sociologische Gids, 25, 273-296.

Peschar, J.L. (1987). Zo vader-zo zoon, zo moeder-zo dochter? Vergelijkende analyses naar de processen van statusverwerving en onderwijsmobiliteit in Nederland, Hongarije en Polen. Lisse: Swets \& Zeitlinger.

Peschar, J.L. (1989). Over kennis en kansen. Onderwijskansen in internationaal en vergelijkend perspectief. Groningen: RUG.

Rosenbaum, J.E. (1976). Making inequality: the hidden curriculum of high school tracking. New York.

Schooler, C. (1972). Childhood Family Structure and Adult Characteristics. Sociometry, 35, 2 255-269.

Slomczynski, K.M., Miller, J. \& Kohn, M.L. (1981). Stratification, work and values. A Polish United States comparison. American Sociological Review, 46, 720-744.

Velden, R.K.W van der (1991), Sociale herkomst en schoolsucces (dissertatie). Het effect van culturele en sociale hulpbronnen op de schoolloopbaan, Groningen: RION, Monografieën Onderwijsonderzoek 10. 